\title{
FIBER MORPHOLOGY AND PHYSICAL PROPERTIES OF BRANCH AND STEM WOOD \\ OF HAWTHORN (CRATAEGUS AZAROLUS L.) GROWN IN ZAGROS FORESTS
}

\author{
Huijun Dong \\ Nanjing Forestry University \\ China \\ Mohsen Bahmani \\ Shahrekord University \\ IRAN \\ Miha Humar \\ University Of Ljubljana \\ Slovenia \\ Sohrab Rahimi \\ University Of British Columbia \\ CANADA \\ (Received July 2020)
}

\begin{abstract}
This study aims at investigating the effect of three altitude levels (below $1800 \mathrm{~m}, 1800-2000 \mathrm{~m}$ and above $2000 \mathrm{~m}$ ) on the physical and biometric properties of stem-wood and branch-wood of hawthorn species. Moreover, the relationship between wood dry density and volumetric swelling, fiber length, fiber diameter, cell wall thickness were studied. Results indicated that altitude had significant effects on the dry density, volumetric swelling and fiber length of stem wood while did not significant effects on the density of branch wood. Additionally, some physical and biometric properties had relatively greater correlation coefficients in branch wood than in stem wood whereas others had higher coefficients in stem wood compared to branch wood. Deep understanding of properties this wood species will provide a fresh insight into the relationship between wood properties and environmental factors.
\end{abstract}

KEYWORDS: Crataegus spp., Zagros, dry density, fiber length, correlation, wood. 


\section{INTRODUCTION}

Iran's forests cover approximately twelve million ha, including five million ha in the mountainous Zagros region (Haidari et al. 2013). The climate in Zagros is mainly affected by westerly disturbances and the Azores high during the cold (November-March) and warm (May-September) season respectively, resulting in a clear distinction between a wet winter and a dry summer. The mean annual temperature of the region is $16^{\circ} \mathrm{C}$ and mean annual precipitation is $509 \mathrm{~mm}$ (Azizi et al. 2012). Zagros forests represents about $40 \%$ of Iranian forests and is the most extensive forest areas of the country (Sagheb-Talebi et al. 2004). The main hardwood species in this area are Quercus spp. (oaks), Pistacia mutica (wild pistachio), Crataegus spp. and Pyrus spp (Jazirehi and Rostaghi 2003). Crategus spp., belonging to the Rosaceae family and Maloideae sub-family including about 300 species which are grown in Europe, North Africa, West Asia, and North America. The scientific name of hawthorn comes from the Greek word "kràtaigos" which means "strength and robustness" due to its hard and durable wood (Nazhand et al. 2020). Crataegus species are small trees, mostly growing up to $15 \mathrm{~m}$. Basic studies in the types of wood species can reveal the possibility of their usage in various applications or lead to create a database of different wood species.

Most studies regarding hawthorn tree species are associated with its distribution and ecological requirements and its physical and fiber biometric properties have not been studied yet. It is indicated that there are variations between wood properties in the stem and branch woods (Kiaei and Roque 2015, Zhao et al. 2018). Several studies have investigated the characteristics of the stem and branch tissue, particularly in terms of anatomical properties, chemical components and physical properties as well as mechanical properties. Dadzie et al. (2018) investigated the density of branch and stem woods in Entandrophragma cylindricum, Entandrophragma angolense and Khaya ivorensis and indicated that the density is significantly higher in branch-wood than stem-wood for all three species. However, Kiaei and Moya (2015) found that the density of stem-wood is higher than that the branch-wood. Zhao et al. (2015) investigated some properties of fiber biometry of root, branch and stem wood of Populus ussuriensis Kom. trees and reported there are significant differences between anatomical characteristics in different parts of the trees. Kiaei et al. (2014) evaluated chemical properties of branch and stem-wood of Plum (Prunus domestica) wood in Iran. They concluded, that lignin and cellulose in branch-wood is higher than in stem-wood. Kiaei et al. (2014) and Dadzie et al. (2018) evaluated some biometrical properties of wood branches and stem in Plum (Prunus domestica) Entandrophragma cylindricum, Entandrophragma angolense and Khaya ivorensis. In general, the results showed that there is a significant difference between the studied parameters. On the other hand, site condition, biotic and edaphic, altitude, aspect and slope of the ground are interacting parameters affecting wood quality (Gava and Goncalves 2008, Murphy et al. 2009, De Micco et al. 2016, Nazari et al. 2020). It is worth mentioning that most studies mainly concentrated on wood properties and ignore the relationship between wood properties and environmental growth variables. To the best of our knowledge, there is no research on the physical and biometrical properties of hawthorn wood (Crataegus azarolus L.). Considering the valuable position of hawthorn wood in the Zagros forests of Iran, current study aims to identify the changes of wood density, fiber length, fiber diameter and cell wall thickness of hawthorn wood in branch and stem woods, comparing the respective factors of hawthorn wood achieved from different altitude levels. 


\section{MATERIAL AND METHODS}

\section{Site area and sample collection}

This study was carried out in trees collected from ecosites (three forest sample stands along an altitudinal gradient (below1800-, 2000-2200 and above $2400 \mathrm{~m}$ a.s.1.) in the hawthorn forests of Bazoft. In each ecosite, three plots were implemented, accordingly the 27 plots were selected in study area. Trees characteristics at nine different ecosites collected wood are given in Tab 1. In total, 27 healthy trees were selected. Hawthorn forests in the current study area are spread between 1500 and $2400 \mathrm{~m}$ in altitude. The mean annual precipitation and temperature of the area are $330 \mathrm{~mm}$ and $14^{\circ} \mathrm{C}$, respectively (Chaharmahal and Bakhtiari Meteorological Administratio, 2020). Forest stands are relatively uniform in size and age as well as extensively dominated by Persian oak with basal area ranging between 57.70 and $113.23 \mathrm{~m}^{2} \cdot \mathrm{ha}^{-1}$. Due to their remote location and the absence of evidence of human impact, it is assumed that all stands have been developed under the influence of natural impacts and disturbances. The maximum rooting depth is frequently limited by a shallow bedrock. In each plot, all live trees of at least $7.5 \mathrm{~cm}$ diameter at breast height (DBH, $1.3 \mathrm{~m}$ above the root collar) were identified, and their diameter at breast height, height, crown length and perpendicular diameters were recorded within 0.1-hectare plot. The caliper, Vertex and diameter tape were used to measurements of trees diameters, height and crown diameter, respectively. Then in each plot, those dominant trees that healthy with the largest diameters at breast height $(\mathrm{DBH})$ without any defects and reaction wood were sampled and one disk from stem and branch was taken from the tree trunk for the determination of wood properties.

Tab. 1: Trees characteristics at nine different ecosites collected wood in Zagros forests.

\begin{tabular}{|c|c|c|c|c|c|c|c|c|c|c|}
\hline \multicolumn{2}{|r|}{ Ecosites } & 1 & 2 & 3 & 4 & 5 & 6 & 7 & 7 & 9 \\
\hline \multirow{8}{*}{$\begin{array}{l}\text { Tree-level } \\
\text { variables }\end{array}$} & ${ }^{2} \mathrm{DBH}$ & $\begin{array}{c}58.67 \\
(11.37)\end{array}$ & $\begin{array}{l}101.00 \\
(23.52)\end{array}$ & $\begin{array}{l}69.33 \\
(6.51)\end{array}$ & $\begin{array}{c}73.33 \\
(12.34)\end{array}$ & $\begin{array}{l}85.00 \\
(7.00)\end{array}$ & $\begin{array}{l}109.67 \\
(45.35)\end{array}$ & $\begin{array}{c}75.33 \\
(16.50)\end{array}$ & $\begin{array}{c}84.33 \\
(27.02)\end{array}$ & $\begin{array}{c}84.67 \\
(10.69)\end{array}$ \\
\hline & Height & $\begin{array}{c}4.48 \\
(0.36)\end{array}$ & $\begin{array}{c}8.71 \\
(0.54)\end{array}$ & $\begin{array}{c}5.13 \\
(0.71)\end{array}$ & $\begin{array}{c}4.86 \\
(1.63)\end{array}$ & $\begin{array}{c}6.20 \\
(1.59)\end{array}$ & $\begin{array}{c}7.25 \\
(3.46)\end{array}$ & $\begin{array}{c}4.84 \\
(1.44)\end{array}$ & $\begin{array}{c}5.63 \\
(0.29)\end{array}$ & $\begin{array}{l}10.76 \\
(5.23)\end{array}$ \\
\hline & Stem basal area & $\begin{array}{c}0.28 \\
(0.10)\end{array}$ & $\begin{array}{c}0.83 \\
(0.37)\end{array}$ & $\begin{array}{c}0.38 \\
(0.07)\end{array}$ & $\begin{array}{c}0.43 \\
(0.15)\end{array}$ & $\begin{array}{c}0.57 \\
(0.09)\end{array}$ & $\begin{array}{l}1.05 \\
(0.84)\end{array}$ & $\begin{array}{c}0.46 \\
(0.20)\end{array}$ & $\begin{array}{c}0.59 \\
(0.36)\end{array}$ & $\begin{array}{c}0.57 \\
(0.15)\end{array}$ \\
\hline & Stem volume & $\begin{array}{c}0.64 \\
(0.27)\end{array}$ & $\begin{array}{c}3.77 \\
(1.82)\end{array}$ & $\begin{array}{c}1.00 \\
(0.15)\end{array}$ & $\begin{array}{c}1.13 \\
(0.66)\end{array}$ & $\begin{array}{c}1.83 \\
(0.75)\end{array}$ & $\begin{array}{c}4.78 \\
(5.62)\end{array}$ & $\begin{array}{c}1.26 \\
(0.83)\end{array}$ & $\begin{array}{c}1.75 \\
(1.10)\end{array}$ & $\begin{array}{c}3.28 \\
(2.35)\end{array}$ \\
\hline & ${ }^{3} \mathrm{ABH}$ & $\begin{array}{l}298 \\
(30)\end{array}$ & $\begin{array}{l}447 \\
(95)\end{array}$ & $\begin{array}{l}323 \\
(10)\end{array}$ & $\begin{array}{l}335 \\
(30)\end{array}$ & $\begin{array}{l}360 \\
(13)\end{array}$ & $\begin{array}{c}468 \\
(180)\end{array}$ & $\begin{array}{l}339 \\
(34)\end{array}$ & $\begin{array}{l}380 \\
(91)\end{array}$ & $\begin{array}{l}369 \\
(36)\end{array}$ \\
\hline & ${ }^{4}$ Crown diameter & $\begin{array}{c}2.58 \\
(0.21)\end{array}$ & $\begin{array}{c}4.65 \\
(0.58)\end{array}$ & $\begin{array}{c}4.62 \\
(0.39)\end{array}$ & $\begin{array}{c}5.23 \\
(0.71)\end{array}$ & $\begin{array}{c}4.25 \\
(0.30)\end{array}$ & $\begin{array}{c}4.78 \\
(0.58)\end{array}$ & $\begin{array}{c}4.25 \\
(0.58)\end{array}$ & $\begin{array}{c}4.77 \\
(1.26)\end{array}$ & $\begin{array}{c}5.97 \\
(1.08)\end{array}$ \\
\hline & Crown basal area & $\begin{array}{c}5.26 \\
(0.83)\end{array}$ & $\begin{array}{l}17.15 \\
(4.09)\end{array}$ & $\begin{array}{l}16.81 \\
(2.87)\end{array}$ & $\begin{array}{l}21.76 \\
(5.94)\end{array}$ & $\begin{array}{l}14.23 \\
(2.00)\end{array}$ & $\begin{array}{l}18.14 \\
(4.50)\end{array}$ & $\begin{array}{l}14.35 \\
(3.82)\end{array}$ & $\begin{array}{l}18.66 \\
(8.85)\end{array}$ & $\begin{array}{c}28.56 \\
(10.00)\end{array}$ \\
\hline & ${ }^{5} \mathrm{MADI}(\mathrm{mm})$ & $\begin{array}{c}1.96 \\
(0.19)\end{array}$ & $\begin{array}{c}2.25 \\
(0.06)\end{array}$ & $\begin{array}{c}2.14 \\
(0.14)\end{array}$ & $\begin{array}{c}2.18 \\
(0.16)\end{array}$ & $\begin{array}{c}2.36 \\
(0.12)\end{array}$ & $\begin{array}{c}2.33 \\
(0.16)\end{array}$ & $\begin{array}{c}2.20 \\
(0.27)\end{array}$ & $\begin{array}{c}2.19 \\
(0.24)\end{array}$ & $\begin{array}{c}2.29 \\
(0.07)\end{array}$ \\
\hline
\end{tabular}

Notes: 1QMD: quadratic mean diameter; 2DBH: diameter at breast height; 3ABH: age at breast height, 4Crown width in $\mathrm{m}$ measured from below the tree in the field; 5MAI: Mean annual diameter increment. Standard deviations are displayed in parentheses. 


\section{Physical properties}

Wood specimens were prepared from the discs cut from stem and branch woods of hawthorn. In detail, specimens with dimensions of $3 \times 2 \times 2 \mathrm{~cm}$ were prepared in accordance with ISO 13061-14 (2016) for the investigation of oven-dry density and volumetric swelling. Sample dimensions were measured in green (saturated) and oven-dry condition with a slide calliper; oven-dry mass was determined with an electric balance to an accuracy of $0.01 \mathrm{~g}$. Volumetric swelling was calculated using the dimensional change from the green to oven-dry condition. The physical properties were calculated according to the following equations:

$$
\begin{aligned}
& \mathrm{D}_{0}=\mathrm{P}_{0} / \mathrm{V}_{0} \\
& \alpha_{\mathrm{v}}=\left(\mathrm{V}_{\mathrm{s}}-\mathrm{V}_{0}\right) / \mathrm{V}_{0}
\end{aligned}
$$

where: $\mathrm{D}_{0}$ - oven dry density $\left(\mathrm{g} \cdot \mathrm{cm}^{-3}\right), \alpha_{\mathrm{v}}$ - volumetric swelling $(\%), \mathrm{V}_{\mathrm{s}}$ - volume in the saturate state $(\mathrm{cm} 3), \mathrm{V}_{0}$ - volume in state of oven-dry $\left(\mathrm{cm}^{3}\right), \mathrm{P}_{0}$ - weight in state of oven dry $(\mathrm{g})$.

\section{Biometric properties}

Separation of individual wood fibre was performed using Franklin (1964) method through which a wood specimens with the dimension of $15 \times 10 \times 2 \mathrm{~mm}^{3}$ were saturated in a mixture (1:1) of acetic acid and oxygenized water in test tubes. Afterwards, the specimens were kept in an oven with $65 \pm 3^{\circ} \mathrm{C}$ for $48 \mathrm{~h}$. After maceration, the specimens were washed (2-3 times) in distilled water and then immersed with distilled water. In the next step, shacked and the biometric parameters (fiber length, fiber diameter, and cell wall thickness) were evaluated by light microscopic. From each slice, at least 50 fibers were used for the measurements.

\section{Statistical analysis}

In this study, the influence of altitude steps was evaluated on the physical and biometric properties. One-way analysis of variance (ANOVA) performed to determine significant differences using SPSS version 25. Pearson correlation matrix was also applied to determine the correlation between dry wood density with volumetric swelling, fiber length, fiber diameter, cell wall thickness.

\section{RESULTS AND DISCUSSION}

\section{Oven-dry density}

The average values of dry wood density obtained for hawthorn wood in three different altitudes are shown in Tab. 2. The highest $\left(0.75 \mathrm{~g} \cdot \mathrm{cm}^{-3}\right)$ and lowest $\left(0.69 \mathrm{~g} \cdot \mathrm{cm}^{-3}\right)$ density values of stem-wood were identified in the intermediate and high altitude, respectively. For branch wood the highest $\left(0.69 \mathrm{~g} \cdot \mathrm{cm}^{-3}\right)$ and lowest $\left(0.65 \mathrm{~g} \cdot \mathrm{cm}^{-3}\right)$ values were found in the intermediate and low altitude, respectively. It is reported that generally density variations related to the anatomical characteristics, e.g. vessel and fibre morphology, ecological site, moisture content and chemical constitutes (Zobel and van Buijtenen 1989, Preston et al. 2006, Sousa et al. 2018, Bahmani et al. 2018). We were not able to fully elucidate specific reasons for variation in density. However, it is planned to perform more targeted research in one of the future studies. Overall, stem wood $\left(0.71{\left.\mathrm{~g} \cdot \mathrm{cm}^{-3}\right)}^{-3}\right.$ showed higher density than branch wood $\left(0.67 \mathrm{~g} \cdot \mathrm{cm}^{-3}\right)$. Similar observations were previously reported by Amoah et al. (2012) for Terminalia ivorensis and Milicia excels, Kiaei and Roque (2015) for Alnus glutinosa, Kotowska et al. (2015) for Theobroma caco and Durio zibethinus and Zhao et al. (2018) for Populus ussuriensis Kom. However, Dadzie et al. (2016) mentioned that branch-wood had higher density than stem-wood. The density of hawthorn wood is equal 
or relatively higher than that of Quercus robur (Wagenführ 1996, $0.69 \mathrm{~g} \cdot \mathrm{cm}^{-3}$ ), Red oak (Zeidler and Borůvka 2016, $0.65 \mathrm{~g} \cdot \mathrm{cm}^{-3}$ or Pedunculate oak (Zeidler and Borůvka 2016, $0.71 \mathrm{~g} . \mathrm{cm}-3$ ). In contrast to the findings, density of $Q$. cerris $\left(0.75 \mathrm{~g} \cdot \mathrm{cm}^{-3}\right.$ Pásztory et al. 2014), and $S$. torminalis $\left(0.83 \mathrm{~g}^{\mathrm{cm}} \mathrm{cm}^{-3}\right.$ Bahmani et al. 2020) are significantly higher than density of hawthorn wood. The results of ANOVA exhibited that the altitude had significant effects on the density of stem-wood while had no significant effects on the density of branch-wood (Tab. 4).

\section{Volumetric swelling}

Tab. 2 shows the mean values of volumetric swelling for hawthorn wood. The highest $(21.42 \%)$ and lowest $(12.70 \%)$ values of volumetric swelling of stem-wood were found in the intermediate and in the low altitude, respectively. The same pattern of density variation was also achieved for branch-wood. Generally, swelling and shrinkage is a parameter that strongly related to wood density. Overall, volumetric swelling in stem-wood $(0.71 \mathrm{~g} . \mathrm{cm}-3)$ found out higher than its branch-wood (0.67 g.cm-3). This correlates well with findings reported by Kiaei and Roque (2015). Generally, swelling and shrinkage is a parameter that strongly related to wood density and microfibrillar angle in the S2 layer of secondary. High wood density has proportionately more cell and less lumen volume, and they shrink and swell more due to the unique nature of the microstructures (Schulgasser and Witztum 2015). From the ANOVA test, it can be derived that the effects of altitude levels on volumetric swelling are significant for stem-wood and not significant for branch-wood (Tab. 4).

Tab. 2: The average of physical properties in three different altitudes of hawthorn wood in Zagros forests.

\begin{tabular}{|l|c|c|c|c|c|c|}
\hline \multirow{3}{*}{ Wood properties } & \multicolumn{9}{|c|}{ Altitude (m) } \\
\cline { 2 - 7 } & \multicolumn{2}{|c|}{ Below 1800 m (low) } & \multicolumn{2}{c|}{$\begin{array}{c}\mathbf{1 8 0 0 - 2 0 0 0 ~ m} \\
\text { (intermediate) }\end{array}$} & \multicolumn{2}{c|}{ Above 2000 m (high) } \\
\cline { 2 - 7 } & Stem & Branch & Stem & Branch & Stem & Branch \\
\hline $\begin{array}{l}\text { Oven-dry density } \\
\left(\mathrm{g} \cdot \mathrm{cm}^{-3}\right)\end{array}$ & 0.69 & 0.66 & 0.75 & 0.69 & 0.70 & 0.65 \\
\hline Volumetric swelling & $(0.05)$ & $(0.04)$ & $(0.06)$ & $(0.04)$ & $(0.07)$ & $(0.05)$ \\
$(\%)$ & 20.31 & 17.78 & 21.42 & 19.45 & 12.70 & 11.65 \\
$(0.98)$ & $(1.43)$ & $(2.45)$ & $(1.22)$ & $(1.34)$ & $(1.78)$ \\
\hline
\end{tabular}

*Values in parenthesis represent standard deviation.

\section{Fiber biometry}

\section{Fiber length}

Fiber morphology are the key elements responsible for the wood strength and play an important role in determining the qualitative and quantitative wood properties and specific usage of lignocellulosic materials (Panshin and de Zeeuw 1980, Gryc and Vavrčík 2005, Nazari et al. 2021). The mean values of the parameter fiber lengths for hawthorn wood in three different altitude levels are given in Tab. 3. The highest $(0.85 \mathrm{~mm})$ and lowest $(0.72 \mathrm{~mm})$ values of fiber length in stem-wood were found in the high altitude and in the intermediate altitude, respectively. On the other hand, the highest $(0.79 \mathrm{~mm})$ and lowest $(0.71 \mathrm{~mm})$ values of fiber length in branch-wood were found in the low altitude and in the intermediate altitude, respectively. Overall, it was observed that stem-wood $(0.80 \mathrm{~mm})$ showed that higher fiber length than branch-wood $\left(0.76 \mathrm{~g}^{\mathrm{cm}}{ }^{-3}\right)$. Branch-wood has moderately shorter fibers than its stem-wood in most hardwoods (Bowyer et al. 2003, Samariha et al. 2011). These might be ascribed to the narrower diameter and shorter length longitudinal cells of branch-wood (Antwi-Boasiako and Apreko-Pilly 2016). 
The measured values of mean fiber length are lower than those of softwood (2.7-4.6 mm, Tsoumis 1996) and close to most hardwood fibers (0.7-1.6 mm, Horn 1978, Tsoumis 1996). According to Wheeler et al. (1989), fibers are classified into three groups: (1) short fibers with a length of less $0.90 \mathrm{~mm}$; (2) fibers of medium leng th between 0.90-1.90 mm such as hawthorn wood with an average fiber length of $0.95 \mathrm{~mm}$; (3) fibers longer than $1.90 \mathrm{~mm}$.

There are significant differences in stem-wood fibre length among the three altitude levels, whereas no significant difference in branch-wood fiber lengths found out among the three altitudes (Tab. 4), what is in line with the density measurements as well.

\section{Fiber diameter}

A maximum value of $20.93 \mu \mathrm{m}$ and a minimum value of $19.99 \mu \mathrm{m}$ for fiber diameter of stem-wood were determined in the low altitude step and in the high altitude, respectively (Tab. 3). For branch-wood, maximum $(22.60 \mu \mathrm{m})$ and minimum $(20.59 \mu \mathrm{m})$ were obtained in the intermediate altitude and at the low altitude, respectively (Tab. 2). In total, fiber diameter in branch-wood $(21.64 \mu \mathrm{m})$ exhibited higher than its stem-wood $(20.19 \mu \mathrm{m})$. The mean value of fiber diameter of hawthorn wood agree with previous research findings for other hardwood fibers (Atchison 1987, San et al. 2016). Plomion et al. (2001) reported that variations in the fiber diameter could have contributed to the molecular and physiological changes occurring in the vascular cambium as well as in the wood cell walls throughout the tree growth. At 5\% significance level, there were significant differences in branch and stem wood fiber diameter among the three altitude levels (Tab. 4).

\section{Cell wall thickness}

Cell wall diameter parameter is variable among species, sites, between and within trees as well as highly associated with wood density. The maximum value of the parameter cell wall thickness $(5.93 \mu \mathrm{m})$ as well as the minimum $(5.67 \mu \mathrm{m})$ were determined for stem wood trees in the intermediate altitude and at the low altitude, respectively (Tab. 3). The maximum $(6.34 \mu \mathrm{m})$ and minimum $(5.74 \mu \mathrm{m})$ values of branch-wood, were acquired in the intermediate altitude and in the low altitude, respectively (Tab. 3). Overall, branch-wood $(5.98 \mu \mathrm{m})$ showed that cell wall thickness higher than stem wood $(5.79 \mu \mathrm{m})$. Similar results were obtained by Kiaei et al. (2014) for plum wood and Zhao et al. (2018) for Populus ussuriensis Kom. At $5 \%$ significance level, there were significant differences in branch and stem wood cell wall diameter among the three altitude levels (Tab. 4).

Tab. 3: The mean parameter of fiber morphology in three different altitudes of hawthorn wood in Zagros forests.

\begin{tabular}{|l|c|c|c|c|c|c|}
\hline \multirow{2}{*}{ Wood properties } & \multicolumn{7}{|c|}{ Altitude (m) } \\
\cline { 2 - 7 } & \multicolumn{2}{|c|}{ Below 1800 m (low) } & \multicolumn{2}{c|}{$\begin{array}{c}\text { 1800-2000 m } \\
\text { (intermediate) }\end{array}$} & \multicolumn{2}{c|}{ Above 2000 m (high) } \\
\cline { 2 - 7 } & Stem & Branch & Stem & Branch & Stem & Branch \\
\hline Fiber length & 0.84 & 0.79 & 0.72 & 0.70 & 0.85 & 0.78 \\
$(\mathrm{~mm})$ & $(0.04)$ & $(0.04)$ & $(0.04)$ & $(0.04)$ & $(0.04)$ & $(0.04)$ \\
\hline Fiber diameter & 20.93 & 21.74 & 19.99 & 22.60 & 20.59 & 11.65 \\
$(\mu \mathrm{m})$ & $(0.04)$ & $(0.04)$ & $(0.04)$ & $(0.04)$ & $(0.04)$ & $(0.04)$ \\
\hline Cell wall diameter & 5.76 & 5.85 & 5.93 & 6.34 & 5.67 & 5.74 \\
$(\mu \mathrm{m})$ & $(0.04)$ & $(0.04)$ & $(0.04)$ & $(0.04)$ & $(0.04)$ & $(0.04)$ \\
\hline
\end{tabular}

*Values in parenthesis represent standard deviation. 
Vol. $66(3): 2021$

Tab. 4: Analysis of variance (ANOVA) of the physical properties of hawthorn wood at different altitude.

\begin{tabular}{|c|c|c|c|c|c|c|c|c|}
\hline $\begin{array}{c}\text { Source } \\
\text { of } \\
\text { variation }\end{array}$ & & $\begin{array}{c}\text { Wood } \\
\text { properties }\end{array}$ & & $\begin{array}{c}\text { Sum } \\
\text { of } \\
\text { squares }\end{array}$ & df & $\begin{array}{l}\text { Mean } \\
\text { square }\end{array}$ & Fvalue & p value \\
\hline \multirow{30}{*}{ Altitude } & \multirow{15}{*}{ Branch } & \multirow{3}{*}{$\begin{array}{l}\text { Oven-dry } \\
\text { density }\end{array}$} & Between groups & 0.011 & 2 & 0.006 & 3.190 & 0.059 \\
\hline & & & Within groups & 0.042 & 24 & 0.002 & & \\
\hline & & & Total & 0.054 & 26 & & & \\
\hline & & \multirow{3}{*}{$\begin{array}{l}\text { Volumetric } \\
\text { swelling }\end{array}$} & Between groups & 405.091 & 2 & 202.546 & 76.658 & 0.000 \\
\hline & & & Within groups & 63.413 & 24 & 2.642 & & \\
\hline & & & Total & 468.504 & 26 & & & \\
\hline & & \multirow{3}{*}{$\begin{array}{l}\text { Fiber } \\
\text { length }\end{array}$} & Between groups & 0.038 & 2 & 0.019 & 1.960 & 0.163 \\
\hline & & & Within groups & 0.234 & 24 & 0.010 & & \\
\hline & & & Total & 0.272 & 26 & & & \\
\hline & & \multirow{3}{*}{$\begin{array}{c}\text { Fiber } \\
\text { diameter }\end{array}$} & Between groups & 18.270 & 2 & 9.135 & 4.717 & 0.019 \\
\hline & & & Within groups & 46.475 & 24 & 1.936 & & \\
\hline & & & Total & 64.746 & 26 & & & \\
\hline & & \multirow{3}{*}{$\begin{array}{l}\text { Cell wall } \\
\text { thickness }\end{array}$} & Between groups & 1.982 & 2 & 0.991 & 6.524 & 0.005 \\
\hline & & & Within groups & 3.647 & 24 & 0.152 & & \\
\hline & & & Total & 5.629 & 26 & & & \\
\hline & \multirow{15}{*}{ Stem } & \multirow{3}{*}{$\begin{array}{l}\text { Oven-dry } \\
\text { density }\end{array}$} & Between groups & 0.019 & 2 & 0.009 & 4.561 & 0.021 \\
\hline & & & Within groups & 0.049 & 24 & 0.002 & & \\
\hline & & & Total & 0.068 & 26 & & & \\
\hline & & \multirow{3}{*}{$\begin{array}{l}\text { Volumetric } \\
\text { swelling }\end{array}$} & Between groups & 387.735 & 2 & 193.868 & 38.871 & 0.000 \\
\hline & & & Within groups & 119.698 & 24 & 4.987 & & \\
\hline & & & Total & 507.434 & 26 & & & \\
\hline & & \multirow{3}{*}{$\begin{array}{l}\text { Fiber } \\
\text { length }\end{array}$} & Between groups & 0.100 & 2 & 0.050 & 3.024 & 0.067 \\
\hline & & & Within groups & 0.397 & 24 & 0.017 & & \\
\hline & & & Total & 0.497 & 26 & & & \\
\hline & & \multirow{3}{*}{$\begin{array}{c}\text { Fiber } \\
\text { diameter }\end{array}$} & Between groups & 7.960 & 2 & 3.980 & 3.474 & 0.047 \\
\hline & & & Within groups & 27.499 & 24 & 1.146 & & \\
\hline & & & Total & 35.459 & 26 & & & \\
\hline & & \multirow{3}{*}{$\begin{array}{l}\text { Cell wall } \\
\text { thickness }\end{array}$} & Between groups & 0.294 & 2 & 0.147 & 3.925 & 0.034 \\
\hline & & & Within groups & 0.898 & 24 & 0.037 & & \\
\hline & & & Total & 1.191 & 26 & & & \\
\hline
\end{tabular}

Tabs. 5 and 6 present the correlation matrixes of the relationships among density and the various characteristics of stem wood, and those among density in branch wood. Results of Pearson matrix correlation showed that the cell wall thickness had significant relationships (i.e. $\mathrm{p}<0.05$ ) with wood density (Tab. 5).

Tab. 5: Correlation matrix for the interrelationships between density and the morphological feathers of stem wood of the hawthorn species.

\begin{tabular}{|l|c|c|c|c|c|}
\hline Stem wood & $\mathbf{1}$ & $\mathbf{2}$ & $\mathbf{3}$ & $\mathbf{4}$ & $\mathbf{5}$ \\
\hline 1. Density & 1 & & & & \\
\hline 2. Volumetric swelling & 0.300 & 1 & & & \\
\hline 3. Fiber length & -0.126 & -0.240 & 1 & & \\
\hline 4. Fiber diameter & -0.056 & 0.280 & -0.029 & 1 & \\
\hline 5. Cell wall thickness & 0.201 & $0.417^{*}$ & 0.030 & -0.070 & 1 \\
\hline
\end{tabular}

${ }^{*}$ Correlation is significant at the 0.05 level. 
As can be seen in Tab.6, fiber diameter and cell wall thickness had significant relationships (i.e. $\mathrm{p}<0.05$ ) with wood density of branch-wood (Tab. 5).

Tab. 6: Correlation matrix for the interrelationships between density and the biometric feathers of branch wood of the hawthorn species.

\begin{tabular}{|l|c|c|c|c|c|}
\hline Branch wood & $\mathbf{1}$ & $\mathbf{2}$ & $\mathbf{3}$ & $\mathbf{4}$ & $\mathbf{5}$ \\
\hline 1. Density $\left(\mathrm{kg} \cdot \mathrm{m}^{-3}\right)$ & 1 & & & & \\
\hline 2. Volumetric swelling & 0.251 & 1 & & & \\
\hline 3. Fiber length & 0.162 & -0.276 & 1 & & \\
\hline 4. Fiber diameter & 0.265 & $0.473^{*}$ & -0.171 & 1 & \\
\hline 5. Cell wall thickness & 0.166 & $0.469^{*}$ & -0.148 & 0.112 & 1 \\
\hline
\end{tabular}

* Correlation is significant at the 0.05 level.

Some biometric properties had moderately higher correlation coefficients in branch-wood than in stem wood whereas others had higher coefficients in stem wood than branch wood (Tabs. 4 and 5). For example, fibre length correlated positively but insignificantly $(\mathrm{r}=0.162, \mathrm{p}>0.05)$ with branch-wood density but inversely and insignificantly $(\mathrm{r}=-0.126, \mathrm{p}>0.05)$ with stem-wood density.

\section{CONCLUSIONS}

This study inspected the influence of different altitude levels on wood physical properties (dry density and volumetric swelling) and biometric properties (fiber length, fiber diameter, cell wall thickness) of hawthorn wood in southwest of Iran. The following results have been obtained: (1) The results of ANOVA indicated that different altitude levels had a significant effect on physical and fiber biometry of both stem and branch woods. (2) There are significant statistical differences of the studied parameters between stem and branch woods. (3) The highest mean values of physical properties (dry density, volumetric swelling) of both stem and branch woods are found in the intermediate altitude. (4) The highest mean values of fiber length, fiber diameter, and cell wall thickness of stem-wood are found in high, low and intermediate altitude, respectively. However, the mentioned properties of branch-wood are found in low and intermediate altitudes above sea level. (5) Pearson matrix correlation indicated that fiber diameter and cell wall thickness have significant relationships with wood density.

\section{REFERENCES}

1. Amoah, M., Appiah-Yeboahand, J., Okai, R., 2012: Characterization of physical and mechanical properties of branch stem and root wood of iroko and emire tropical trees. Research Journal of Applied Sciences, Engineering and Technology 4(12): 1754-1760.

2. Antwi-Boasiako, C., Apreko-Pilly, S., 2016: Termite resistivity of the stem and branch woods of Aningeria robusta and Terminalia ivorensis. African Journal of Wood Science and Forestry 4(2): 231-237.

3. Atchison, J.E., 1987: Data on non-wood plant fibers. In: The Secondary fibers and non-wood pulping (3. ed. Hamilton F and B Leopold). TAPPI Press, Atlanta, USA, 391 pp. 
4. Azizi, G., Arsalani, M., Bräuning, A., Moghimi, E., 2013: Precipitation variations in the central Zagros Mountains (Iran) since AD 1840 based on oak tree rings. Palaeogeography, Palaeoclimatology, Palaeoecology 386: 96-103.

5. Bahmani, M., Saeedi, S., Humar, M., Kool, F., 2018: Effect of tree diameter classes on the properties of Persian oak (Quercus brantii lind1.) wood. Wood Research 63(5): 755-762.

6. Bahmani, M., Fathi, L., Koch, G., Kool, F., Aghajani, H., Humar, M., 2020: Heartwood and sapwood features of Sorbus torminalis grown in Iranian forests. Wood Research 65(2): 195-204.

7. Bowyer, J., Shmulsky, R., Haygreen, J.G., 2003: Forest products and wood science: An introduction. Fourth edition. Ames, IA: Blackwell Publishing Professional, 478 pp.

8. Dadzie, P.K., Amoah, M., Ebanyenle, E., Frimpong-Mensah, K., 2018: Characterization of density and selected anatomical features of stemwood and branchwood of E. cylindricum, $E$. angolense and $K$. ivorensis from natural forests in Ghana. European Journal of Wood and Wood Products 76(2): 655-667.

9. Dadzie, P.K., Amoah, M., 2015: Density, some anatomical properties, and natural durability of stem and branch wood of two tropical hardwood species for ground applications. European Journal of Wood and Wood Products 73(6): 759-773.

10. De Micco, V., Campelo, F., De Luis, M., Bräuning, A., Grabner, M., Battipaglia, G., Cherubini, P., 2016: Intra-annual density fluctuations in tree rings: how, when, where, and why? IAWA Journal 37(2): 232-59.

11. Gava, J.L., Goncalves, J.L.M., 2008: Soil attributes and wood quality for pulp production in plantations of Eucalyptus grandis clone. Journal of Agriculture Science 65(3): 306-313.

12. Gryc, V.L., Vavrčík, H.A., 2005: Effect of the position in a stem on the length of tracheids in spruce (Picea abies (L.) Karst.) with the occurrence of reaction wood. Journal of Forest Science 51: 203-212.

13. Haidari, M., Namiranian, M., Gahramani, L., Zobeiri, M., Shabanian, N., 2013: Study of vertical and horizontal forest structure in Northern Zagros Forest (Case study: West of Iran, Oak forest). European Journal of Experimental Biology 3(1): 268-278.

14. ISO 13061-14, 2016: Physical and mechanical properties of wood. Test methods for small clear wood samples. Part 14. Determination of volumetric shrinkage. Geneva, Switzerland.

15. Jazirehi, M.H., Rostaghi, E.M., 2003: Silviculture in Zagros. University of Tehran Press, Tehran, 520 pp.

16. Kiaei, M., Roque., R.M., 2015: Physical properties and fiber dimension in stem, branch and root of alder wood. Fresenius Bulletin 24(1b): 335-342.

17. Kiaei, M., Tajik, M., Vaysi, R., 2014: Chemical and biometrical properties of plum wood and its application in pulp and paper production. Maderas. Ciencia y tecnología 16(3): 313322.

18. Kotowska, M.M., Hertel, D., Rajab, Y.A., Barus, H., Schuldt, B., 2015: Patterns in hydraulic architecture from roots to branches in six tropical tree species from cacao agroforestry and their relation to wood density and stem growth. Frontiers in Plant Science 6: 1-17.

19. Murphy, G., Brownlie, R., Kimberley, M., Beets, P., 2009: Impacts of forest harvesting related soil disturbance on end-of-rotation wood quality and quantity in a New Zealand radiata pine forest. Silva Fennica 43(1): 147-160.

20. Nazari, N., Bahmani, M., Kahyani, S., Humar, M., Koch, G., 2020: Geographic variations of the wood density and fiber dimensions of the Persian oak wood. Forests 11(9): 1003. 
21. Nazari, N., Bahmani, M., Kahyani, S., Humar, M., 2021: Effect of site conditions on the properties of hawthorn (Crataegu azarolus L.) wood. Journal of Forest Science 67(3): 113-124.

22. Nazhand, A., Massimo, L., Alessandra, D., Massimo, Z., Santo, C., Selma B. Souto, A.M., Silva, P.S., Eliana B.S, Antonello, ؟., 2020: Hawthorn (Crataegus spp.): An updated overview on its beneficial properties. Forests 11(5): 564.

23. Panshin, A.J., Zeeuw, C.D., 1980: Texthook of wood technology. Volume I. Structure, identification, uses, and properties of th: commercial woods of the United States and Canada, 3rd ed. McGraw-Hill, New York, USA, 391 pp.

24. Pásztory, Z., Börcsök, Z., Ronyecz, I., ]Mohácsi, K., Molnár, S., Kis, S., 2014: Oven dry density of sessile oak, turkey oak and hc rnbeam in different region of Mecsek Mountain. Wood Research 59(2): 683-694.

25. Plomion, C., Leprovost, G., Stokes, A., 2001: Wood formation in trees. Plant Physiology 127(4): 1513-1523.

26. Preston, K.A., Cornwell, W.K., DeNoyer, J.L., 2006: Wood density and vessel traits as distinct correlates of ecological strate $3 y$ in 51 California coast range angiosperms. New Phytologist 170(4): 807-818.

27. Sagheb-Talebi, K., Sajedi, T., Yazdian, F., 2004: Forests of Iran. Research Institute of Forests and Rangelands. Forest Researc r division 339: 28.

28. Samariha, A., Kiaei, M., Talaeipour, M., Nemati, M., 2011: Anatomical structural differences between branch and trunk in Ailanthus altissima wood. Indian Journal of Science and Technology 4(12): 1676-1678.

29. San, H.P., Long, L.K., Zhang, C.Z. Hui, T.C., Seng, W.Y., Lin, F.S., Hun, A.T., Fong, W.K., 2016: Anatomical features, fiber morphological, physical and mechanical properties of three years old new hybrid paulownia: Green Paulownia. Journal of Forest Research 10(1): 30-35.

30. Schulgasser, K., Witztum, A., 2015: How the relationship between density and shrinkage of wood depends on its microstructure. Wood Science and Technology 49: 389-40.

31. Sousa, V.B., Louzada, J.L., Pereira, H., 2018: Variation of ring width and wood density in two unmanaged stands of the Mediterranean Oak Quercus faginea. Forests 9(1): 44.

32. Tsoumis, G., 1996: Science and technology of wood: structure. Properties and utilization, Van Nostrand Reinhold, New York. USA, 268 pp.

33. Vaysi, R., Yosefi, F., 2008: An investigation on the production possibility of NSSC pulp and fluting papers from Kiwi residues. Journal of Sciences and Techniques in Natural Resources 3(1): 51-64.

34. Wagenführ, R., Scheiber. C., 1974: Holzatlas. Leipzig, Fachbuchverlag, 690 pp.

35. Wheeler, E.A., Baas, P., Gasson, P.E (eds), 1989: IAWA list of microscopic features for hardwood identification. IAWA Bulletin n.s. 10(3): 219-332.

36. Zeidler, A., Borůvka, V., 2016: Wood density of northern red oak and pedunculate oak grown in former brown coal mine in the Czech Republic. Bioresource 11(4): 9373-9385.

37. Zhao, X., 2015: Effects of cambial age and flow path-length on vessel characteristics in birch. Journal of Forest Research 20(1): 175-185.

38. Zhao, X., Guo, P., Zhang, Z., Wang, X., Peng, H., Wang, M., 2018: Wood density and fiber dimensions of root, stem, and branch wood of Populus ussuriensis Kom. Trees. BioResources 13(3): 7026-7036.

39. Zobel, B.J., van Buijtenen, J.P., 1989: Wood variation: Its causes and control. SpringerVerlag, Berlin, Heidelberg, New York, 378 pp. 


\author{
Huijun Dong \\ Nanjing Forestry University \\ College Of Material Science And Engineering \\ NANJING 2 IOO37 \\ China \\ Mina Humar \\ University Of Ljubljana \\ Department Of Wood Science \\ Biotechnical Faculty \\ I5OI LJUBLJANA \\ Slovenia \\ Sohrab Rahimi \\ University Of British Columbia \\ Department Of Wood Science \\ Vancouver, BC V6T $1 Z 4$ \\ CANADA \\ Mohsen Bahmani* \\ ShaHreKord University \\ Department Of Natural Resources And Earth Science \\ SHAHREKORD 64I65478 \\ IRAN \\ *Corresponding author: mohsen.bahmani@sku.ac.ir
}


